\title{
An Evaluation of Green Banking Practices in Bangladesh
}

\author{
Mohammad Hassan Shakil* Md. Kazi Golam Azam and Mohammad Sharif Hossain Raju \\ Department of Business Administration, International Islamic University Chittagong, 240 Nabab Serajdullah \\ road, Chittagong-4203, Bangladesh. \\ Assistant Professor, Department of Business Administration, International Islamic University Chittagong, 240 \\ Nabab Serajdullah road, Chittagong-4203, Bangladesh. \\ *Corresponding Author's Email: hassan.shakil007@gmail.com
}

\begin{abstract}
Green Banking is any form of banking that benefits the environment. Green banking shifts banks from the 'profit, profit and profit motive to 'planet, people and profit' motive. Green banking is very important in mitigating the Credit Risk, Legal Risk, Security Risk and Reputation Risk in the banking sector. The study mainly aims to analyze the Green Banking practices among SCBs, SDBs, PCBs and FCBs in Bangladesh. The study is of analytical and theoretical in nature based on secondary data. The study finds that $\mathbf{4 7}$ banks have adopted the Green Banking policy, formed Green Banking Unit, allocated and utilized budget for green banking. But the allocation and utilization of budget of SCBs and SDBs are not satisfactory. Online banking and ATM facilities of SCBs and SDBs are very poor. It is also found that there is a sharp increase in giving loans to environmentally friendly projects by banks. Researcher found that some banks still do not and some banks are in the first phase in the policy guideline set by BB. The greatest reason for not adopt Green Banking perhaps is that it often require a large initial cost. As SCBs and SDBs are far behind to adopt online banking and ATM facilities, our government should provide enough fund and technical support to them. Bangladesh Bank should enforce SCBs, SDBs, PCBs and FCBS, that they should assess the sensitive issues like vulnerable groups; involuntary displacement etc while investing or funding the projects.
\end{abstract}

Keywords: $\mathrm{GB}=$ Green Banking, $\mathrm{FCBs}=$ Foreign Commercial Banks, $\mathrm{PCBs}=$ Private Commercial Banks, SCBs $=$ State owned Commercial Banks, SDBs $=$ Specialized Development Banks.

\section{Introduction}

'Green' in some studies refers to define a broad range of social, ethical and environmental practices. Though, for the purpose of the study that tends to look into environmental aspect, "green" in the discussion primarily describe banks' impacts on the environment, environmental responsibility as well as environmental performances in their activities. Green banking means promoting environmental-friendly practices and reducing carbon footprint from banking practices. This could be done in many ways such as by using online banking instead of branch banking, paying bills online instead of mailing them, opening up CDs and money market accounts at online banks instead of large multi-branch banks or finding the local bank in your area that is taking the biggest steps to support local green initiatives. As one of the least developed countries Bangladesh is the worst sufferer of world environmental pollution through industrialization of the western countries. Under such extreme environmental threat, the financial sector of Bangladesh is playing a key role as one of the important stake-holders of the economy enforcing the businessmen/ industrialists of the country to design their various strategy/action plans keeping in mind the crucial environmental issues. Green banking (GB) is a component of the global initiative by a group of stakeholders to save the environment.

\section{Objectives of the study}

The study mainly aims to analysis the green banking practices among State-owned Commercial Banks (SCBs), Specialized Development Banks (SDBs), Private Commercial Banks (PCBs) and Foreign Commercial Banks (FCBs) in Bangladesh. To attain the main objective, the study considers the following objectives in particular:

> To examine the Green Banking initiatives in Bangladesh.

$>$ To evaluate the Green Banking performance of banks in Bangladesh.

\section{Methodology of the study}

The present study is of analytical and theoretical in nature and based on secondary data. Secondary data sources have been collected from various newspapers, magazines, internet and commercial banks websites and Bangladesh Bank websites etc. Furthermore, different working papers, journals and articles have been studied to enrich the literature of the study. An intensive desk research has been undertaken to collect published data. The collected data are analyzed in the viewpoint of development and competency of green banking activities in 
Bangladesh. Microsoft office package have been used for summarizing and illustrating the collected data systematically.

\section{Literature Review}

The term Green Banking is now popular worldwide now-a-days. It is for stopping the environmental degradation and making this planet habitable. The concept of Green Banking was developed in the western countries. Green banking is a general term, which can cover a multitude of areas from a bank being environmentally friendly to how and also where their money is invested.

Though Green Banking is popular, several literatures and studies have been found regarding 'Green Banking' in USA, Europe, China, India and Bangladesh from 2000 to 2012. Among them some popular studies have been reviewed and explained here to support this paper and make the paper literally viable and sound.

At first I would like to explore the evolution of Green Banking. In 2003, the Equator Principles (EPs) were launched and were initially adopted by some leading global banks, such as Citigroup Inc., The Royal Bank of Scotland, Westpac Banking Corporation. It serves as "a set of voluntary standards for determining, assessing and managing social and environmental risk in project financing" (EPs, 2006). The EPs is based the performance standards on social and environmental sustainability of the International Financial Initiatives (IFI) and World Bank Group's Environmental, Health and Safety general guidelines, and it provides a common benchmark and framework for project finance. The adopting entities, known as Equator Principles Financial Institutions (EPFIs), make their own social and environmental policies, procedures and standards for their financing activities, and ensure not to give loans to projects where the borrowers do not comply with the standards stated in the EPs. At the same time, EPFIs have responsibilities to ensure the borrowers know the content of principles and to guide them on how to incorporate principles into planned project.

Atiur Rahman (2010) in his paper focused on the present monetary and credit policy of Bangladesh Bank towards attaining broader financial enclosure. Bangladesh Bank is carry forwarding with technology driven, innovative, environment and low cost banking approach; conveying a qualitative change in banking, preparation of monetary policy, application of advanced banking technology, and use of Information and Communication Technology (ICT) to extend financial services to the door step of common people. To ensure access to financial services for all, various initiatives have been taken like trade finance; digitalization of the financial sector; channeling liquidity into productive and supply augmenting investments including agriculture, SMEs, Green Banking and CSR activities; expected to lead to more broad

-based inclusive growth and therefore lessen poverty; required for pushing the country on course to the targeted vision of digital Bangladesh by 2021; the year of Golden Jubilee of their independence.

Alice Mani (2011) indicated that as Socially Responsible Corporate Citizens (SRCC), banks have a major role and responsibility in enhancement of governmental efforts towards substantial reduction in carbon emission. Banks can practices and initiatives of Green Banking for sustainable development. The author examined and compared the green lending policies by banks in India in the light of their compliance and commitment to environment protection and environment friendly projects.

Green Banking Policy of BASIC Bank Limited, Bangladesh (2011) was go forwarded in response to increasing consciousness over climate change, environmental degradation, need for urgent measures for sustainable development to be addressed by some of the stakeholders in the world. Banking system holds a unique position in an economy that can affect production, business and other economic activities through their procedure for financing activities which would in turn contribute to protect environment/climate from pollution. Moreover, efficiency in energy use, water consumption and waste reduction may significantly contribute for operating cost for many of the large banks of the country.

Mohmed Aminul Islam (2010) showed in his report that green Banking is also significant issue in recent times. While the banking industry is undergoing computerization, networking and offering of on-line banking is naturally gaining momentum development in this sector.

Suresh Chandra Bihari (2011) elucidated that Green Banking includes promoting corporate social responsibility (CSR). It starts with the aim of protecting the environment where banks consider before financing a project whether it is environment friendly and has any implications for the future. A company will be given a loan only when all the environmental safety standards are followed. Green Banking can be efficiently implemented through the use of technology and policy, he emphasized. 
In the book "Sustainable Finance and Banking" (2001), the author Marcel Jeucken has identified four phases action that banks should take for sustainability. They are sequentially defensive banking, preventative banking, offensive banking and sustainable banking. In this model, the bank that has several business divisions is classified as a whole entity. And the first three terms are defined as the stages or attitudes of banking with respect to environmental issues. His study actually pioneers the path of green or socially responsible banking system.

In 2012, Md. MarufUllah in his study on 'Green Banking in Bangladesh- a Comparative Analysis' denoted "As per entity concept banks are responsible corporate citizens. Banks believe that every small 'GREEN' step taken today would go a long way in building a greener future and that each one of them can work towards to better global environment. Overall Green banking is really a good way for people to get more awareness about global warming; each businessman will contribute a lot to the environment and make this earth a better place to live."

\section{Green Banking Practices \& Initiatives in Bangladesh}

\subsection{Policy Formulation \& Governance}

In 201247 commercial banks have formulated Green Banking Policy Guidelines approved by their Board of Directors and formed Green Banking Unit (GBU) for Green Banking activities. 44 banks have their Green Office Guide for in-house green activities.

\subsubsection{Budget Allocation and Utilization}

Bangladesh Bank have made provision to allocate a considerable amount of money for green banking in banks annual budgets, which should include Budget for green finance, Climate Risk Fund and Marketing, Training \&

\begin{tabular}{|ll|}
\hline Area & $\begin{array}{l}\text { Utilization Amount } \\
\text { (in million taka) }\end{array}$ \\
\hline Green Finance & 270921.53 \\
\hline Climate Risk Fund & 258.89 \\
\hline Marketing, Training \& Capacity Building & 90.42 \\
\hline
\end{tabular}

Capacity Building.

39 Banks have utilized 271270.84 million taka in 2012 for green finance, Part of CSR activities for Green Project and Event and Marketing, Training and Capacity Building.

Source: Bangladesh Bank-Annual Report on Green Banking 2012

\subsubsection{EnvRR information during 2012}

Since July 2011 Banks have started Environmental Risk Rating (EnvRR). Banks have done environmental risk rating in 4394 and 12088 projects in 2011 and 2012 respectively. Similarly 4315 and 11165 projects (disbursed amount is Tk. 270951.14 \& 703633.21) have been financed after rating in 2011 and 2012 respectively.

\begin{tabular}{|lll|}
\hline Environmental Risk Rating & $\mathbf{2 0 1 1}$ & $\mathbf{2 0 1 2}$ \\
\hline Year & 4394 & 12088 \\
\hline Number of Projects Rated & 4315 & 11165 \\
\hline $\begin{array}{l}\text { No. of Projects Financed after } \\
\text { Rating }\end{array}$ & & 703633.21 \\
\hline $\begin{array}{l}\text { Amount Disbursed to the Rated } \\
\text { Projects } \\
\text { (in million taka) }\end{array}$ & 270951.14 & \\
\hline
\end{tabular}




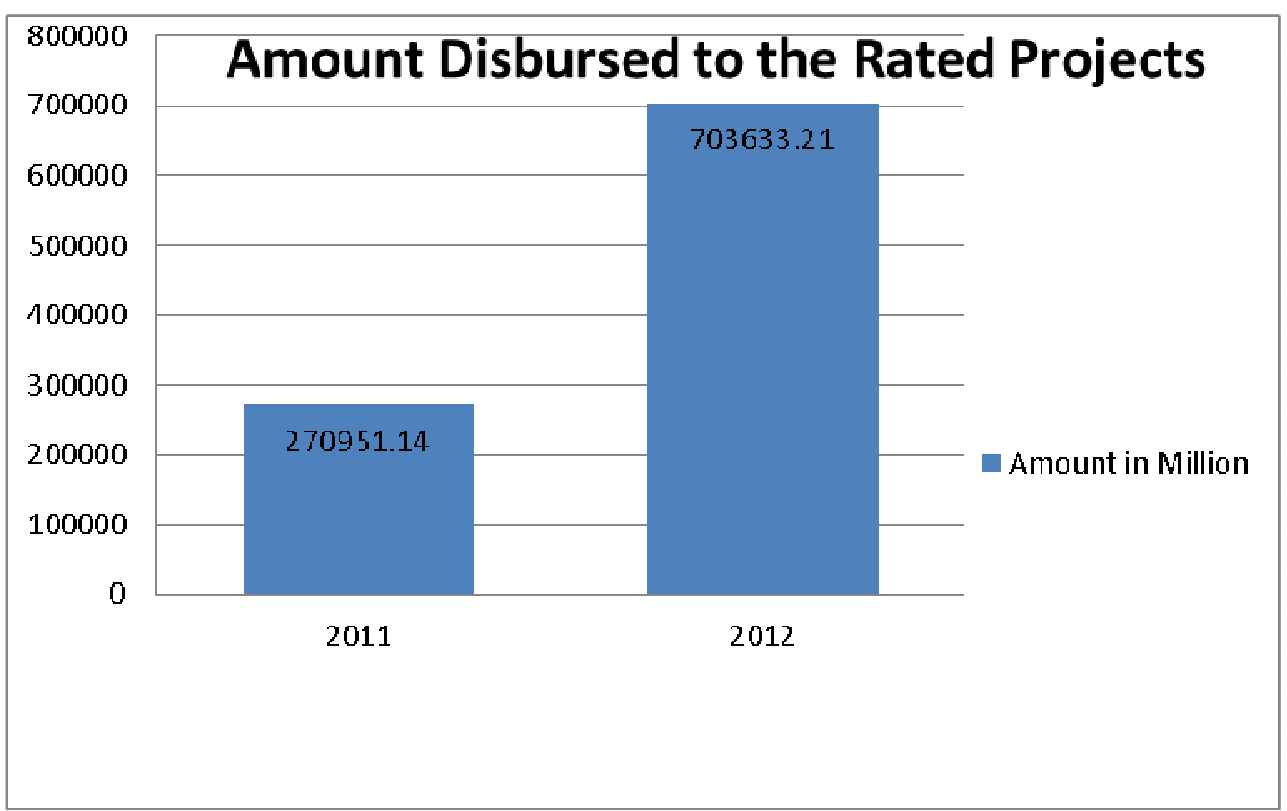

Fig: Amount Disbursement to Rated Projects

In the above figure we can clearly see that the numbers of projects rating in 2012 have increased more than three times higher than the previous year. In 2011 and 2012 the disbursed amount is $\mathbf{2 7 0 9 5 1 . 1 4}$ and $\mathbf{7 0 3 6 3 3 . 2 1}$ million taka respectively.

\subsubsection{Green Finance}

Green Finance includes both direct and indirect finance. Sources of bank's direct finance may be bank's own fund or Bangladesh Bank's fund for renewable energy and projects which are environment friendly. Projects having ETP or alike system are included in the indirect finance.

\begin{tabular}{llll}
\hline $\begin{array}{l}\text { Bank } \\
\text { Category }\end{array}$ & $\begin{array}{l}\text { Direct } \\
\text { Green } \\
\text { Finance }\end{array}$ & $\begin{array}{l}\text { Indirect } \\
\text { Green } \\
\text { Finance }\end{array}$ & Total \\
\hline SCB's & 3513.10 & 2994.15 & 6507.25 \\
PCB's & 5623.74 & 173187.17 & 178810.91 \\
FCB's & 881.28 & 76517.03 & 77398.31 \\
SDB's & 1803.36 & 6401.70 & 8205.06 \\
Total & 11821.48 & 259100.05 & $\mathbf{2 7 0 9 2 1 . 5 3}$ \\
\hline
\end{tabular}

Banks have disbursed in different green products/events as taka 1356.52 million in ETP, taka 259100.05 million in project having ETP, taka 899.87 million in Bio-gas plant, taka 3638.37 million in solar/ renewable energy and taka 1830.33 million in HHK etc. during 2012. 


\begin{tabular}{|c|c|c|c|c|c|}
\hline Green Projects & SCB'S & PCB's & FCB's & SDB's & $\begin{array}{l}\text { Total } \\
\text { (Million taka) }\end{array}$ \\
\hline ETP & 118.81 & 687.89 & 162.8 & 387.02 & 1356.52 \\
\hline Projects having ETP & 2994.15 & 173187.17 & 76517.03 & 6401.70 & 259100.05 \\
\hline Bio-gas Plant & 9.73 & 283.82 & 0 & 606.32 & 899.87 \\
\hline $\begin{array}{l}\text { Solar/Renewable } \\
\text { Energy Plant }\end{array}$ & 984.94 & 1685.56 & 718.48 & 249.39 & 3638.37 \\
\hline Bio-fertilizer Plant, & 0.00 & 0.40 & 0 & 0 & 0.40 \\
\hline $\begin{array}{l}\text { Hybrid Hoffman } \\
\text { Kiln (HHK) }\end{array}$ & 538.71 & 841.96 & 0 & 449.66 & 1830.33 \\
\hline Others & 1860.91 & 2089.58 & 0 & 110.97 & 4061.76 \\
\hline $\begin{array}{l}\text { Reduced Rate of } \\
\text { Interest }\end{array}$ & 0.00 & 34.26 & 0 & 0 & 34.26 \\
\hline
\end{tabular}

\section{Source: Bangladesh Bank- Annual Report on Green Banking 2012}

\subsubsection{Climate Risk Fund}

Banks have allocated taka 2145.35 million in 2012 as climate risk fund. Bank's climate risk fund covers their CSR activities as green events or green projects. In 2012, 258.89 million taka have utilized by banks from their Climate Risk Fund. Banks in general have not yet responded well in terms of utilizing Climate Risk Fund. Banks have utilized only $12.07 \%$ against total allocation. Out of taka 2145.35 million, Private Commercial Banks (PCBs) have utilized taka 219.70 million $(84.86 \%)$ maximum contribution whereas State Owned Commercial Banks (SCBs) and Specialized Development Banks have only $9.5 \%$ and $0 \%$ respectively.

\begin{tabular}{|lll|}
\hline Bank Category & Budget Allocation & $\begin{array}{l}\text { Budget Utilization } \\
\text { (Total) }\end{array}$ \\
\hline SCB's & 415.00 & 24.61 \\
\hline PCB's & 1283.15 & 219.70 \\
\hline FCB's & 17.00 & 14.58 \\
\hline SDB's & 430.20 & 0.00 \\
\hline Total & 2145.35 & 258.89 \\
\hline
\end{tabular}

\section{CSR activities for green event / project}

\subsubsection{Online, Internet \& SMS Banking}

Online banking service is expanding day by day along-with the increase in number of branches with online coverage and accounts facilitated with internet and SMS banking.

\begin{tabular}{|l|l|l|l|}
\hline Type of Banks & Total number of Branches & $\begin{array}{l}\text { Number of branches with } \\
\text { online banking facility }\end{array}$ & $\begin{array}{l}\text { of branches with online } \\
\text { banking facility }\end{array}$ \\
\hline SCB's & 3482 & 177 & 5.08 \\
\hline PCB's & 3378 & 3116 & 92.24 \\
\hline FCB 's & 75 & 75 & 100.00 \\
\hline SDB's & 1457 & 77 & 5.28 \\
\hline Total & 8392 & 3445 & 41.05 \\
\hline
\end{tabular}

Scenario of Online banking looks very promising. A total of 3445 out of 8392 number of branches i.e. $41.05 \%$ are equipped with online banking services. 37 banks mainly private and foreign commercial banks are fully automated ensuring online banking services in each of their branches. 92.24\% of the total branches of PCBs have been brought under online banking coverage. 5.08\% of the total branches of State Owned Commercial Banks (SCBs) and $5.28 \%$ of Specialized Development Banks have been brought under online banking coverage respectively. 


\begin{tabular}{|l|l|l|}
\hline Types of Banks & $\begin{array}{l}\% \text { of accounts facilitated } \\
\text { with Internet banking }\end{array}$ & $\begin{array}{l}\% \text { of accounts facilitated with } \\
\text { SMS banking }\end{array}$ \\
\hline SCB's & $0.00 \%$ & $0.01 \%$ \\
\hline PCB's & $2.62 \%$ & $7.73 \%$ \\
\hline FCB 's & $35.71 \%$ & $39.64 \%$ \\
\hline SDB's & $0.00 \%$ & $0.00 \%$ \\
\hline Total & $1.22 \%$ & $3.20 \%$ \\
\hline
\end{tabular}

Banks have started to concentrate on mobile banking, SMS banking and internet banking. It shows from the returns that $3.20 \%$ and $1.22 \%$ of the total number of accounts have been facilitated with SMS banking and internet banking respectively. The State-owned Commercial Banks (SCBs) and Specialized Development Banks need to go a long way in Online, Internet \& SMS Banking.

\subsubsection{ATM services by Banks}

Most of the banks have been offering 24/7 banking services through their countrywide ATM booths. At present 4738 ATM booths are operating in Bangladesh. Dutch-Bangla Bank is in the top position with installation of 2366 ATMs. BRAC and AB Bank are in the second and third position with 317 and 222 ATMs respectively.

\subsubsection{Branches/ SME/ATM units powered by Solar Energy}

\begin{tabular}{|l|l|l|}
\hline Types of Banks & $\begin{array}{l}\text { Branches powered by solar } \\
\text { energy }\end{array}$ & $\begin{array}{l}\text { SME/ATM units powered by } \\
\text { solar energy }\end{array}$ \\
\hline SCB's & 21 & 8 \\
\hline PCB's & 169 & 150 \\
\hline FCB 's & 22 & 0 \\
\hline SDB's & 2 & 3 \\
\hline Total & 214 & 161 \\
\hline
\end{tabular}

Source: Bangladesh Bank- Annual Report on Green Banking 2012

At present 214 branches of 26 banks are powered by solar energy. 23 branches of Islami, 16 branches of both Sonali \& Al-Arafah and 14 branches of Merccantile Bank Ltd. are powered by solar energy.

161 SME/ATM units of 9 banks are powered by solar energy. BRAC Bank has 131 SME/ATM units powered by solar energy. Other banks such as Sonali, AB, Prime, Mutual Trust, Islami, Standard Chartered, HSBC and Bank Al-Falah have SME/ATM units powered by solar energy.

\subsubsection{Major Green Banking Activities in 2012 at a glance}

Green Banking unit has been established in 47 banks.

$>$ Green Office Guide has been introduced by 47 banks.

$>$ EnvRR has been done for $\mathbf{1 2 0 8 8}$ projects.

$>\mathbf{1 1 1 6 5}$ rated projects have been financed.

$>$ 703633.21 million taka has been disbursed.

> 214 branches and 161 ATM/SME unit offices are powered by solar energy.

$>37$ banks are fully automated.

> 3445 branches have been facilitated with online coverage.

$>$ Taka 270921.53 million has been disbursed as green finance.

$>$ Taka $\mathbf{2 5 8 . 8 9}$ million has been utilized from climate risk fund.

$>$ In green marketing, training and development $\mathbf{9 0 . 4 2}$ million taka has been utilized

\subsubsection{Top Ten Banks in Green Banking Initiatives}

Top 10 banks are evaluated on the basis of their overall Green Banking activities. An effort has been made to evaluate top ten banks on each criterion such as Environmental Risk Rating (EnvRR), green finance, part of CSR activities for green event or green project, green marketing, training \& development, in house green activities, online banking and other green banking activities. Bank's green banking activities as of 2012 and also data on last quarter of 2012 have been taken into due consideration while grading top ten banks. 


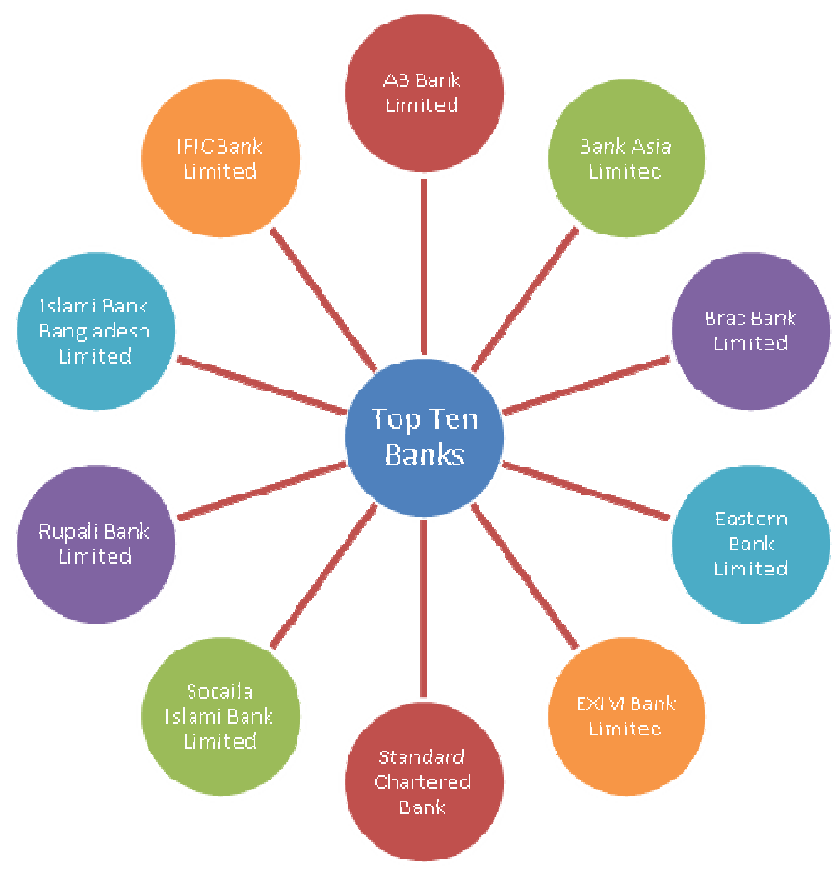

\section{Findings}

$>$ Implementations of various existing guidelines of Green Banking by banks are still largely voluntary in nature. Most of the PCBs and FCBs adopted the policy of Green Banking except SCBs and SDBs. They have not yet taken any step to adopt the policies. In the nature of bank management practices in Bangladesh GB practices get less priority as they are not considered as mandatory.

$>$ The credit assessment and management framework prescribed by Bangladesh Bank and currently followed by all the scheduled commercial banks i.e. Credit Risk Management (CRM) does not include any risk criteria for considering environmental and social issues of a particular loan project. Most of the banks have launched their own environmental risks assessment framework and no clear direction is provided regarding quantification and addition of environmental risk in CRM.

$>$ Online Banking and ATM facilities are regarded as the first step in implementing green banking as it reduces lots of paper works and satisfies the principle of cleanliness at bank. But most of the SCBs and SDBs are still practicing online banking at poor level and ATM facilities are not also satisfactory.

$>$ Green Banking motivates the banking that reduces use of paper which create brand image. It also creates awareness amongst the stakeholders about the environment as well as environment friendly business practices. But very few of our banks have been able to build such green banking image.

\section{Recommendations}

$>$ Banks should ensure finance in projects those are environment friendly or ethical in nature. Investment should be increased for projects installing solar energy plant, bio-gas, bio-fertilizer plants, Effluent Treatment Plant (ETP), Hybrid Hoffman Kiln projects.

Banks should invest in a project after assessing its environmental or climate risk. Investment should only be given after being assessed the environmental risks of particular project. Banks should introduce new environment friendly products such as Green Home Loan, Green Car Loan and others in this regard. 
Deposits of clients are the main sources of capital for the banks. To collect money from the clients, banks provide different deposit services. All of the deposit products should be made environment friendly and should be brought under on-line management.

$>$ Uses of papers encourage flattening of plants and lead the environment to destruction. Considering the environmental risk, banks should minimize the use of papers otherwise introduce the use of eco-friendly papers. They should stop unnecessary printing and use both side of papers and eco-fonts while printing.

$>$ Banks should start E-recruitment system and provide salary and bonus to employee through on-line system. In addition banks should train their employees as environment specialists and welfare worker along with making them skilled bankers.

$>$ Banks can play direct or indirect roles in combating natural disasters. After such diverse situation banks can provide financial supports, aids and interest free loans etc. to support the sufferers to survive in the newer environment.

Banks should arrange several seminar and symposiums to make their clients conscious regarding Green Banking as well as to introduce their Green Products and services therein. This can eventually make the clients adapted to the Green Banking activities.

\section{Conclusion}

Bangladesh is one of the most climate change vulnerable countries in the world. As banks indirectly contribute to environmental pollution through investing in different pollutant industries, we need to take steps against all the wrong doing. Bangladesh Bank which has the legal power to shape the behavior of the banks, it will have to force all the banks to implement green banking policy to curb its own environmental pollution, giving loans to environmentally friendly projects and reducing investment in environmentally harmful projects. Government should also encourage the general people about the green banking practices. The central bank should also monitor commercial banks whether they are practicing green banking or not. Thus green banking can play a significant role in implementing the broader concept of sustainable economic development.

\section{References}

$>\quad$ Atiur Rahman, "Financial Services at People's Doorstep", Governor, Bangladesh Bank, 2010

$>\quad$ Alice Mani, "Green Banking through Green Lending”, www.ibmtedu.org/GVCG/Papers/IC-140.pdf201

$>\quad$ ATM, viewed: October 28,2012

Read more: http://www.investopedia.com/terms/a/atm.asp\#ixzz2AfRDds17

$>\quad$ Bai, Y 2011, 'Financing a Green Future' MS thesis, Lund, Sweden, IIIEE

Theses2011:02,Viewed:September15,2012

http://lup.lub.lu.se/luur/download?func=downloadFile\&recordOId=2203222\&fileOId=2203226

BB Green Banking policy, viewed: July 21, 2012,

http://www.basicbanklimited.com/files/Green_Banking_Policy_Guidelines_of_Bang ladesh_Bank.pdf

$>\quad$ Bangladesh Bank (2011), Policy Guidelines for Green Banking, available at

http://www.bangladeshbank.org/mediaroom/circulars/brpd/feb272011brpd02e.pd

$>\quad$ Bangladesh Bank (2012), Green Banking Report, Green Banking and CSR Department.

$>\quad$ Equator Principles (2011), About equator principles, available at http://www.equator principles.com/index.php/about-ep/about-ep.

$>\quad$ Green Banking Policy of BASIC bank ltd, Bangladesh, Head Office, Dhaka, http://www.basicbanklimited.com/Green_Banking.php

$>\quad$ Hayder, M.M 2012, 'Green Banking and its practice in Bangladesh', Term paper, CU, Viewed: June

2012,http://www.scribd.com/doc/96449881/Green-Bankingand- Its-Practices-in-Bangladesh-ID-07303125

$>\quad$ Rashid, M 2010, 'Green banking comes to focus' Sept. 17, viewed: August

7,2012http://www.thedailystar.net/newDesign/newsdetails.php?nid=15469 
> Rahman, A. 2012 'Green Banking and Sustainable Development: the Case of Bangladesh', UN Conference on Sustainable Development (Rio+20 Summit) Rio de Janeiro, Brazil, June 19, 2012

$>\quad$ Verma, MK 2012, 'Green Banking: A Unique Corporate Social Responsibility of India Banks', International Journal of Research in Commerce \& Management, Vol no. 3 (2012), Issue no. 1 (JANUARY) or www.ijrcm.org.in.

www.bangladeshbank.org.bd viewed: July, August, September, October, 2012 
The IISTE is a pioneer in the Open-Access hosting service and academic event management. The aim of the firm is Accelerating Global Knowledge Sharing.

More information about the firm can be found on the homepage:

http://www.iiste.org

\section{CALL FOR JOURNAL PAPERS}

There are more than 30 peer-reviewed academic journals hosted under the hosting platform.

Prospective authors of journals can find the submission instruction on the following page: http://www.iiste.org/journals/ All the journals articles are available online to the readers all over the world without financial, legal, or technical barriers other than those inseparable from gaining access to the internet itself. Paper version of the journals is also available upon request of readers and authors.

\section{MORE RESOURCES}

Book publication information: http://www.iiste.org/book/

\section{IISTE Knowledge Sharing Partners}

EBSCO, Index Copernicus, Ulrich's Periodicals Directory, JournalTOCS, PKP Open Archives Harvester, Bielefeld Academic Search Engine, Elektronische Zeitschriftenbibliothek EZB, Open J-Gate, OCLC WorldCat, Universe Digtial Library, NewJour, Google Scholar

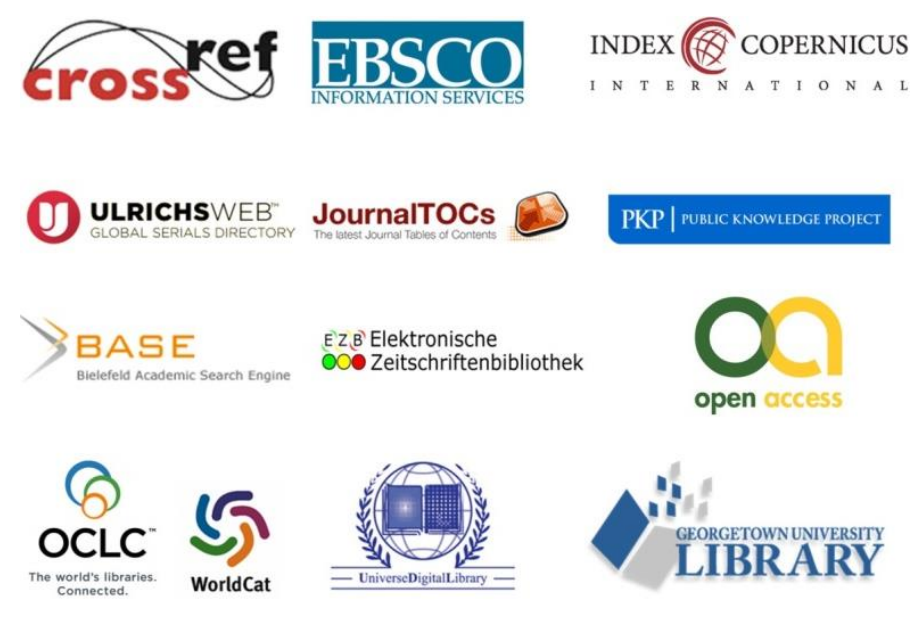

